\title{
Understanding the HRM-Performance Link: A Literature Review on the HRM Strategy Formulation Process
}

\author{
Natalia García-Carbonell ${ }^{1}$, Fernando Martín-Alcázar ${ }^{1} \&$ Gonzalo Sánchez-Gardey $^{1}$ \\ ${ }^{1}$ Business Management Department, University of Cádiz, Cádiz, Spain \\ Correspondence: Natalia García-Carbonell, Business Management Department, University of Cádiz, Cádiz, Spain. \\ E-mail: natalia.carbonell@uca.es
}

Received: January 12, 2014

Accepted: February 6, $2014 \quad$ Online Published: March 2, 2014

doi:10.5430/ijba.v5n2p71

URL: http://dx.doi.org/10.5430/ijba.v5n2p71

The research project described in this paper has been developed under the Research Group SEJ-449 from the Andalusian Government (Andalusian Plan for R+D+I 2007-2013) and the Research Project ECO2011-26982, from the Spanish Ministry for Science and Technology (Non-oriented Fundamental Research Projects Subprogram).

\begin{abstract}
Although most studies in strategic human resource management literature have deeply examined the relationship between HRM and performance, extant literature has shown mixed and inconclusive results. In general, researchers have usually focused on how organizations implement their HRM strategies, using the traditional 'content perspective'. In this sense, SHRM literature has paid less attention to the antecedents of these strategies and the internal dynamic by which HRM systems are defined. Therefore, considering the importance of formulation processes recognized in strategic process research, we propose an integrative model of study focused on the HRM strategy formulation process. From this point of view, we also identify different contingent factors that may impact this strategic process, trying to shed some more light on the complexity of this topic of research. Conclusions and implications of the study will be also discussed.
\end{abstract}

Keywords: strategic human resource management, HR strategy formulation, process

\section{Introduction: Justification and Objectives}

Strategic human resources management (SHRM) emerges as a discipline focused on the strategic contribution of human component in organizations. In the late 1970s, several studies have stressed the need to reorient traditional human resource management (HRM) in order to understand human resources as a crucial element in organizational success. Thus, this traditional view begins to undergo significant changes, focusing its interest on the strategic value of human resources (Lengnick-Hall, Lengnick-Hall, Andrade, \& Drake, 2009). Consequently, the HR function has a more proactive role and a long-term orientation what implies some changes in top management teams' and HR managers' roles. From this point of view, the literature has proposed new models of study that allow the analysis of this strategic dimension. Therefore, SHRM discipline has increasingly incorporated theoretical arguments from different fields of research to build models more complex and complete. However in spite of the rapid evolution of the field, the relationship between HRM and performance still remains unclear. Reviews by Paauwe (2009), Lengnick-Hall et al. (2009), Guest (2011) and Wright and McMahan (2011) demonstrate that there is a need for more research on certain classic and unanswered issues to clearer understand the way HRM influences organizational performance. To echo these calls from the literature this study presents a comprehensive review in an attempt to clarify what we know about the way organizations design their HRM strategies. Then, adopting a 'process model focus' instead of the traditional 'content view' (Bowen \& Ostroff, 2004; Guest, 2011), we identify and classify diverse influencing factors that may lead HRM systems fail. To do so, a theoretical model of study is proposed with a twofold objective: (1) the description of the HRM strategy formulation process and, (2) the identification of contingent factors that may influence on the formulation process.

The paper will be structure in four main sections. We firstly review the literature to define a standard HRM formulation process, identifying key stages and involved actors. Adopting this approach, main influencing factors in 
each stage will be examined to build the new model of analysis. Finally, conclusions, implications and future research lines will be discussed.

\section{Theoretical Background}

\subsection{The HRM Strategy Formulation Process: Main Characteristics and Involved Agents}

The importance of the formulation stage process has been widely recognized in strategic process literature (Hutzschenreuter \& Kleindienst, 2006). Traditionally, this stage has been considered as the core step in strategic decision making, establishing the main aspects for subsequent implementation (Lyles \& Mitroff, 1980). Generally, many SHRM works have examined HRM contents, but in last years, some scholars have stressed the importance of analyzing the internal dynamic of HRM strategic processes (Bowen \& Ostroff, 2004; Becker \& Huselid, 2006; Guest, 2011).

Because of the complexity of this field of research, several theoretical frameworks and perspectives have been combined to explain the HRM strategy formulation process. Nevertheless, in strategic literature most investigations are in agreement over the definition of the strategic process concept. In this sense, early works have pointed out that formulation is one of the stages in strategic decision making process which consists of identifying, analyzing and deciding about relevant strategic issues in organizations (Dutton, Fahey, \& Narayanan, 1983). Specifically, strategic issues are considered as those events that can heavily impact organizational performance (Ansoff, 1980). Later studies have completed this general definition, specifying a sequence of three actions: (1) environmental scanning, (2) interpretation and, (3) strategic choice (Ford \& Goia, 2000). Drawing on previous arguments, environmental scanning is defined by Thomas et al. (1993) as those actions that allow top managers to gather selective information from internal (Cowan, 1986) and external contexts (Milliken, 1990) based on their own perceptions (Pfeffer \& Salancik, 1978). In the HRM strategy formulation process, managers will extract sensitive information that could have important impact on the HR area (Lundy, 1994; Wright, Snell, \& Jacobsen, 2004; Krishnan \& Singh, 2011). On the other hand, interpretation actions are related to the way top managers understand and perceive relevant information. In this respect, they usually categorize and label strategic issues in opportunities and threats (Jackson \& Dutton, 1988; Julian \& Ofori-Dankwa, 2008). Considering the information they have selected and analyzed, top managers will make a strategic choice (Mintzberg \& Waters, 1985; Noble, 1999). As it can be concluded, these three main steps are widely used in specific literature to explain formulation stage process (Figure 1). Considering this process, it can be argued that if formulation stage included the similar steps in any cases, the process would be the same in any organization. Nevertheless, as Wright et al. (2004) pointed out, this process is not universal. To reinforce this argument, there is a dominant stream of research showing that SHRM processes have to be studied taking into account contingent factors (Martín-Alcázar, Romero-Fernández \& Sánchez-Gardey, 2005). Before starting with the analysis of these factors, we will go into the formulation process in depth to specify some of the more important characteristics embraced by the literature.

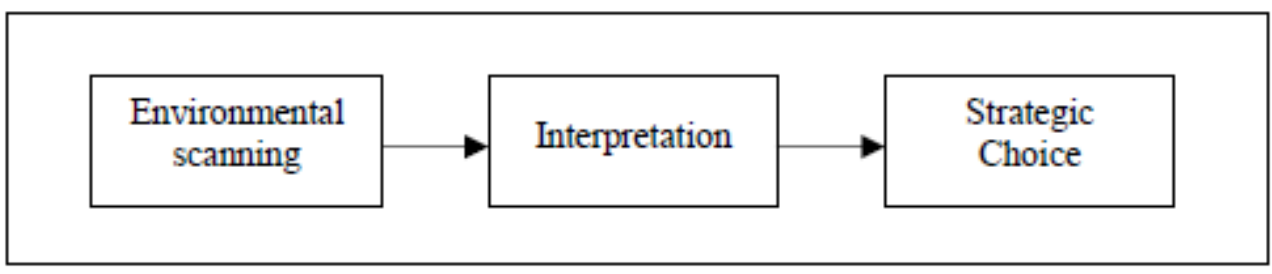

Figure 1. Traditional model of strategy formulation process

Source: Own elaboration

In the SHRM discipline, some researches have also contemplated a similar sequence of actions to describe the HRM strategy formulation. Peery and Salem (1993) propose a model composed of four main activities: (1) strategic issue identification, (2) strategic issue analysis, (3) strategy formulation and, (4) policy implementation. The three first actions would be related to formulation stage as we have pointed out previously. In this case, the strategic issue identification includes the environmental scanning. More specifically, the top management team analyzes the external and internal context to identify relevant aspects that may affect the HR function. They also categorize strategic issues based on their perceptions, considering the opportunity/threat classification. The second step, the strategic issue analysis, is focused on generating different alternatives of actions, evaluating and choosing an efficient alternative. The selected action has to be consistent with the previous analysis. Thirdly, the top management 
team will formulate the concrete HRM strategy and the specific policies. Managers should define HRM policies to face the new external demands.

On the other hand, Wright et al. (2004) also propose a study in which different dimensions of the HRM strategy formulation are examined. In order to define the formulation process, these authors consider several stages: (1) environmental scanning, (2) strategic issues identification, (3) critical human resources identification, (4) strategy development and, (5) communication. When explaining the sequence of actions to develop the formulation process, Wright et al. (2004) include explicitly two key aspects that are not showed in previous studies: the critical human resources identification and the HR communication. Consequently, they propose a more complex and integrative process. Secondly, another interesting conclusion explains that, although Wright et al. (2004) define an ideal process, not all organizations carry out this process similarly. In fact, in some cases, this process does not take place explicitly. As we mentioned above, diverse contingent factors should be considered in the HRM strategy formulation process to understand this dynamic from a broad perspective. Once we have specified the formulation stage, the next step is to describe its main characteristics and involved agents. To do so, we will define five main phases: (1) environmental scanning, (2) strategic issue identification, (3) critical HR identification, (4) definition of the HR orientation and, (5) HR communication.

\subsubsection{Environmental Scanning}

In this part of the HRM formulation process, top management teams have to analyze the environmental context constantly to get relevant information and to adapt, maintain or change the current strategy (Floyd \& Lane, 2000). In this sense, Fredickson (1984) defined the concept strategic decision comprehensiveness as the extent to which managers gather and process environmental information in strategic decision making. This argument shows that it is crucial to gather information systematically and to analyze this information exhaustively (Forbes, 2007). From a different point of view, Raes, Heijltjes, Glunk and Roe (2011) describe the scanning process as the detection of discontinuities in the environment. This process refers to the activities by which top management teams and middle managers interpret, analyse and filter information from the external context, adapting the current strategy to new situations and demands. Diverse studies have shown that during the environmental scanning participation between managers implies will be positive because they will be able to share more information from different points of view (Rindova, 1999). Furthermore, both parts, top management teams and middle management incorporate their perspectives and interpret information collaboratively. The literature has discussed that although comprehensive analysis of the environment is extremely relevant, not always is efficient. It implies important costs in terms of time, resources (Forbes, 2007), and in some unstable environments, a high degree of comprehensiveness will lead top teams to handle with contradictory information (Hough \& White, 2003). This stresses the importance of the intuitive processes (Miller \& Ireland, 2005; Elbanna \& Child, 2007). In this line, Grant (2003) also argues that intuition will increase creativity and flexibility in decision making process, what is needed in the strategy formulation, especially in dynamic and changing environments. Thus, Khatri and $\mathrm{Ng}$ (2000) find that intuitive processes are positively related to organizational performance in unstable environments and negatively in stable environments. Therefore, some degree of intuition may be necessary in scanning environments to promote speed, agility and quality of decisions (Burke \& Miller, 1999). These arguments explain that, in certain contexts, there is a need to implement extremely comprehensive processes to search for information (Miller, 2008). Both processes, intuitive and exhaustive processes need to be combined.

\subsubsection{Strategic Issues Identification}

Following the strategic issue diagnosis literature, managers' interpretation about environmental information is critical for organization success, because it will have effects on alternatives and concrete actions (Dutton \& Duncan, 1987). The way they classify strategic issues will clearly affect strategic responses (Chattopadhyay, Glick, \& Huber, 2001). Works in this area have examined the opportunity/threat perspective that builds a theoretical model based on rational normative theory (Julian \& Ofori-Dankwa, 2008). In this case, authors emphasize that managers categorize strategic issues in two main groups: opportunities or threats. In this categorization process, top managers will not need much time or cognitive resources. In fact, Dutton (1993) pointed out categorization can become more automatic depending on different aspects. Following these arguments, top managers could interpret information more automatically if they faced a familiar issue, considering their past experiences. In some cases, issue urgency or organizational past performance can promote or hinder the automatic interpretation. Nevertheless, more recent studies, such as Julian \& Ofori-Dawnka (2008), have studied this topic in depth by proposing an integrative model of 
categorization called "FUI framework" in which three main attributes of strategic issues -favorability, urgency, influence- will be analyzed.

\subsubsection{Critical Human Resources Identification}

From an internal point of view, managers have to consider and analyze internal information to complete the HRM strategy formulation process (Lundy, 1994; Wright et al., 2004; Chen \& Chang, 2010). Human capital heterogeneity in organizations makes necessary to differentiate between core employees and their contribution to organisational performance and those workers who support the main activity of the firm. Diverse researches suggest that competitive advantages have gone from being supported in some generic resources to depend on idiosyncratic capabilities created from key competencies of employees (Soderquist, Papalexandris, Ioannou \& Prastacos, 2010). According to this, during general strategy formulation process, an internal analysis of core competences is developed. Top managers may assess critical human resources and competences considering "uniqueness" and "strategic value" criteria (Lepak \& Snell, 1999, 2002). By doing so, top management teams will be able to assess human assets and competences that organization posses to face new external challenges. We adopt this stage as a mediating process between issue identification and system design phases. This internal analysis and the environmental scanning explained above, complement each other to enrich the HRM strategy formulation process. Recent studies are considering middle managers role in providing top managers with relevant information about diverse functional areas (Raes et al., 2011). Therefore, HR department and HR manager implication will be crucial aspects in this internal focus (Ulrich, Brockbank \& Johnson, 2009).

\subsubsection{Definition of the HRM Orientation}

Once top teams have developed previous stages, the next step is to define specific HR policies and practices according to the information about competences. SHRM literature has shown that several HR configurations could coexist depending on diverse types of human capital existing in organizations (Lepak \& Snell, 1999, 2002). This means that firms will internally develop necessary competences and, simultaneously, they can purchase other skills in the labour market, depending on its needs. In this stage, the literature considers particularly relevant three main factors in the literature: (1) HRM system flexibility, which explains the ability to reconfigure established HR policies, (2) HR manager participation in strategic decision making and, (3) influence of industrial relations (labour regulation and trade unions influence).

\subsubsection{HR Communication}

The last step in the HRM strategy formulation is related to the communication of the new set of policies and practices. In this sense, Wright et al. (2004) stress the importance of line managers in translating HR messages once they have received the information from the strategic apex. In some cases, communication is also considered as a mechanism to show the importance or involvement of the HR function in organizations. Nevertheless, results evidence that, in general, top management teams communicate the strategy to the line managers using hard copies. In this respect, specialized literature has pointed out that informal HR strategies and inaccessible documents lead to ambiguous perceptions of the role HR function in organizations (Wright et al., 2004; Stanton, Bartram \& Leggat, 2010). Recently, Stanton et al. (2010) have explored how SHRM is understood, interpreted and communicated across the management hierarchy. Results show that the role played by the CEO is determinant to provide HR legitimacy and leadership, as well as to reach agreement between top management team members on HR role. Furthermore, top management teams need to transmit consistent information about HR strategy throughout the hierarchy to get an efficient HR implementation. Then, messages sent by top managers can be inconsistent and ambiguous, reflecting a lack of legitimacy and agreement among team members. Therefore, one of the first indicators to include defining the construct will be the presentation of the HR information and the accessibility for the entire organization. Also, we will consider the implication of top managers and line managers to transmit coherent messages (Den Hertog, Iterson \& Mari, 2010) and the existence of available and efficient channels of communication (Stanton et al., 2010). 


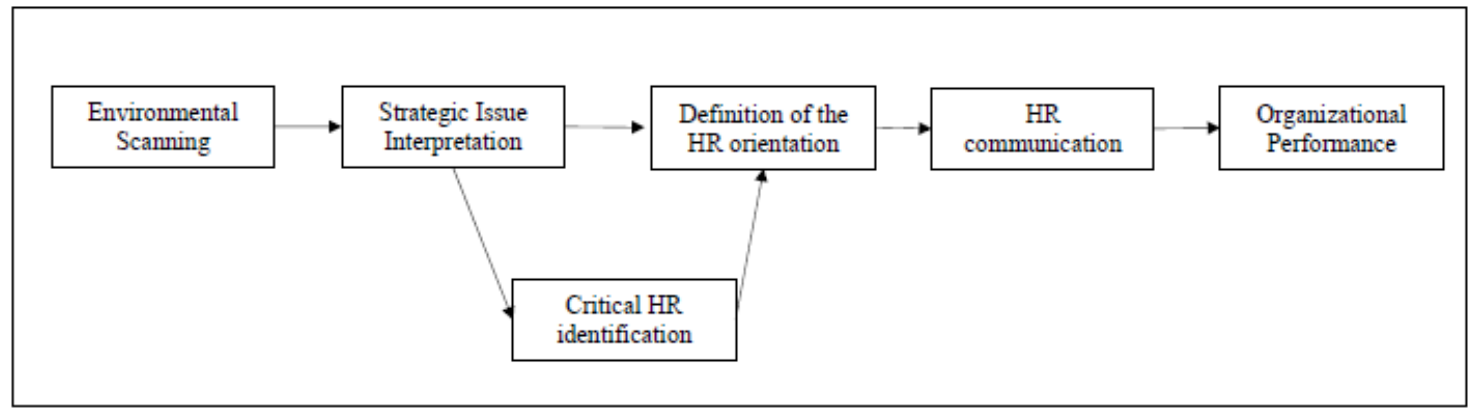

Figure 2. The five-stage HRM strategy formulation process

Source: Own elaboration

\section{Influencing Factors in HRM Strategy Formulation Stage}

HRM strategy formulation process is usually affected by different internal and external factors. Because of the complexity of the formulation dynamic, we will follow the strategic fit literature to explain the antecedents of HRM strategies and the top management team literature to deepen the influence of team composition on the process described. The first dimension, antecedents, will include environmental factors, strategic factors and organizational factors. These factors are completely coherent with contingent and contextual SHRM literature (Martín-Alcázar et al., 2005). The second dimension, TMT composition, will include the analysis of both, demographic and human capital characteristics. With this analysis, we try to present a broad framework that include potential variables to explain deeper the way HRM contributes to organizational success.

\subsection{Antecedents}

Environmental factors: drawing on strategic literature, aspects such as labour market, economic situation or social environment may affect the HRM strategy design (Lundy, 1994). Other authors have stressed the importance of the competence, new technologies, or government regulations (Jackson \& Schuler, 1995; Mello, 2001). In addition, from a macro-social point of view (Brewster, 1993, 1995, 1999), HRM strategies will be also explained considering their effects on social, institutional and political environment. Boon, Paauwe, Boselie and Den Hartog (2009) have shown diverse factors such as government, professional associations, trade unions, works councils and employees also influence how to manage human resources.

Strategic factors: focusing on these factors, business strategy is one of the most studied variables. Miles and Snow (1984) also analyze the link between specific business strategies and certain human resource policies. Similarly, Devanna, Fombrun and Tichy (1984) have discussed a theoretical framework about the analysis organizational and external factor that could determine organizations' survival. In their contribution, these authors define the HR function as a crucial mechanism to carry out the business strategy. Therefore, the alignment between formal organizational structure and HRM systems is needed. In a similar vein, Schuler and Jackson (1987) have argued that depending on the business strategy, HR practices should have a different orientation, assuming assume the coherence between organizational objectives and the HR strategy orientation (McMahan et al., 1999). In 1985, Golden and Ramanujam tried to go a step further into this issue, and showed different links between business and human resource strategies: (1) the administrative role of HR function, (2) one-way link between business strategy and HR strategy (Delery \& Doty, 1996; Devanna et al., 1984; Schuler \& Walker, 1990), (3) a bidirectional and reciprocal relationship between both strategies and (4) a whole integration of HR function in the strategic process.

Organizational factors: there is an important stream of research that considers organizational factors in the HRM strategy formulation process. For instance, size, technology, level of innovation or structure (Jackson, Schuler \& Rivero, 1989; Jackson \& Schuler, 1995) or internal political relationships (Balkin \& Bannister, 1993) may influence the nature of the HRM strategy. Moreover, organizational culture and the role played by HR managers will be determinant factors in the HRM strategy formulation. In this respect, Wei and Lau (2005) and Wei, Liu, Zhang and Chiu (2008) show that organizational culture influences the way top managers perceive human resources in organizations. This argument starts from the premise of organizational culture reflects top manager values and beliefs (Bowen \& Ostroff, 2004). Due to the fact that they are main actors in facing strategic decisions, these values and beliefs are reflected in their choices (Hambrick \& Mason, 1984; Hambrick, 2007). According to this, organizational culture and HRM strategy could be linked and the first (culture) can be antecedent of the second one (HRM strategy) (Wei et al., 2008). Therefore, it is crucial to consider how top management teams perceive HR value and the effect of these perceptions on formulation process (Carmeli \& Schaubroeck, 2005). Secondly, related to the 
HR representation in the organization, we will refer to the role of HR managers in formulation stage, as a mean to express how important HRM is to achieve strategic objectives. In this sense, studies in this area have analyzed the role played by HR managers in strategic decision-making, stressing the importance of his/her participation (Ulrich et al., 2009). Specifically, these studies emphasize that HR managers should contribute to formulation stage, but his / her contribution will be relevant depending on specific HR skills (Lawson \& Limbrick, 1996).

When top managers design their HRM strategies considering the influence of these factors, the SHRM literature traditionally defines this alignment as the vertical fit. However, not only this vertical fit is required to define a consistent HRM strategy, but the coherence between HR practices (horizontal fit) need to be also considered when specifying the set of HR actions Both conditions need to be met to assure that HRM is able to affect organizational performance.

\subsection{Top Management Team Composition}

Prior research paid special attention to the influence of top teams demographic characteristics in strategic decisions (Hambrick \& Mason, 1984). These authors argued that observable attributes could be valid and reliable indicators of managers' experiences, values, skills and information sources (Jehn, Northcraft \& Neale, 1999; Joshi \& Roh, 2009). The way in which managers interpret the environment and strategic issues is conditioned by their characteristics and it strongly influences the interpretation of information, determining decision-making process (Finkelstein \& Hambrick, 1996). Subsequently, several authors have conducted studies based on the Upper Echelon theory proposed by Hambrick and Mason (Hope-Pelled, Eisenhardt \& Xin, 1999; Carmeli \& Schaubroeck, 2005; Tuggle, Schnatterly \& Johnson, 2010). These works have included certain demographic variables, reaching very different conclusions and, in some cases, contradictory results. Such inconclusive evidence is due to the limitations arisen from the use of demographic attributes as approximations of the underlying characteristics of individuals (Hambrick \& Mason, 1984; Forbes \& Milliken, 1999; Nielsen, 2010).

Given these arguments, our study proposes to go a step further in Hambrick and Mason's (1984) assumptions. In this sense, while the Upper Echelon theory focuses mainly on the analysis of demographic characteristics, this research establishes as a starting point this limitation, and we will define different characteristics, both demographic and human capital, which will be included in the theoretical model.

In order to define top team demographic composition, we will take into consideration Lawrence (1997) and Hope-Pelled et al.'s (1999) arguments. These authors distinguish between two different categories of attributes which can determine teams characteristics: (1) immutable attributes, including aspects such as age, gender and nationality and (2) background traits, considering education level, tenure, functional background and educational background.

Given these two sets of observable characteristics, we will focus on three aspects of human capital. Following Milliken and Martins (1996) and more recently, Gallén (1997, 2006), human capital composition can be explained referring to cognitive styles because of its importance to describe how top executives perceive and process information. Secondly, as Lin (2001) points out, individual values will also explain human capital traits. Finally, our proposal includes certain managerial skills related to HRM decisions. Considering these characteristics we complete the human capital construct with some particular skills and abilities of decision-makers (Snell \& Dean, 1992; Lepak \& Snell, 1999). These skills can show us the competence profile of the managers (specialists-generalists) (Kang \& Snell, 2009). All these demographic and unobservable variables will affect the HRM formulation process in different ways.

\section{Conclusions, Implications and Future Research Lines}

Drawing on the literature review, we can conclude that, despite the strategic importance of the HR function is clear in extant literature, more research is need to clarify the internal dynamic of the HRM formulation. In this way, we can better understand the reasons why human resources are considered in different ways in organizations. As discussed, this fact can be explained by the importance of diverse contingent factors that have impact on this strategic process and how they are interpreted and analyzed by top managers and HR executives. To go a step further in these processes we follow traditional arguments that propose three main actions in strategy formulation stage: environmental scanning, interpretation and strategic choice or response. To apply these arguments to the HR area, we complete Wright et al.'s (2004) HRM formulation definition. Nevertheless, an exhaustive analysis of this sequence of actions requires deeper study of the contingent factors that affect this strategic process. To do so, we base on the fit perspective to describe some factors that will determine the HRM strategy. In this sense, we have defined the main variables related to environment, strategic factors and organizational determinants. Moreover, we also introduce some arguments from top management team composition to describe those relevant demographic and human capital attributes for HRM formulation processes. As a result of this literature review we propose an integrative model for HRM strategy formulation process (Figure 3). With this model we contribute to the extant 
literature in two ways: (1) we propose an HRM review from the 'process' perspective to explain HRM/performance relationship, following recent calls from the literature (Guest, 2011). In this line, we provide researchers and managers with a process model in which we have identified necessary steps to design the HRM strategy efficiently in organizations. With this, we also offer to managers a practical and systematic vision about how to create an efficient HRM strategy, establishing main steps and recommendations, (2) we also present a wide and complete theoretical model in which determinant contingent factors are included, allowing researchers and practitioners to have a clear vision about what needs to be carefully considered in HRM strategy formulation processes.

Although the model has not been tested empirically yet, we stress some relevant implications for managers. Firstly, we assume that, in reality, the HRM formulation process is more complicated than we expected. However, our analysis allows us to provide managers with a useful and clear guide about how to face HRM processes. One of the advantages of our theoretical model is that the standard HRM formulation process can be applied in both, large and small companies. It also offers interesting recommendations about those aspects that need to be considered in each HRM stages. For instance, the importance of implementing comprehensive and intuitive processes in the environmental scanning, the application of 'uniqueness' and 'strategic value' criteria to identify core employees or considerations to achieve an efficient HR communication (written and accessible documents, managers implication, appropriated information channels, etc). With the definition of the HRM formulation processes, managers will be able to analyse and assess their skills and reinforce them to develop each HRM stage. Moreover, it could be useful for managers to predict problems derived from the HRM strategy in advance. Secondly, managers can seize the analysis of contingent factors so as to focus on relevant elements, allowing more rapid and efficient HRM processes.

Nevertheless, the following limitations need to be considered when interpreting the conclusions and implications of the theoretical model. It is important to mention that, although we have proposed a universal and linear sequence of actions, in real situations, the HRM strategy formulation may be a dynamic and cyclical process. Additionally, not all contingent factors will have the same weight in different organizations. We also highlight that the model follows a broad perspective, therefore more theoretical refinement is required. Consequently, interesting conclusions and professionals implications may arise from empirical analysis in future research. Perhaps, to conduct the empirical analysis, the model might be divided in different parts to conduct a deeper analysis of the HRM formulation process and the influence of certain determinants in each stage. In this sense, some HRM processes, as the vertical and horizontal fit (Samnani \& Singh, 2013) or internal communication processes (Kidron, Tzafrir, Meshulam \& Iverson, 2013) required to be examined deeper.

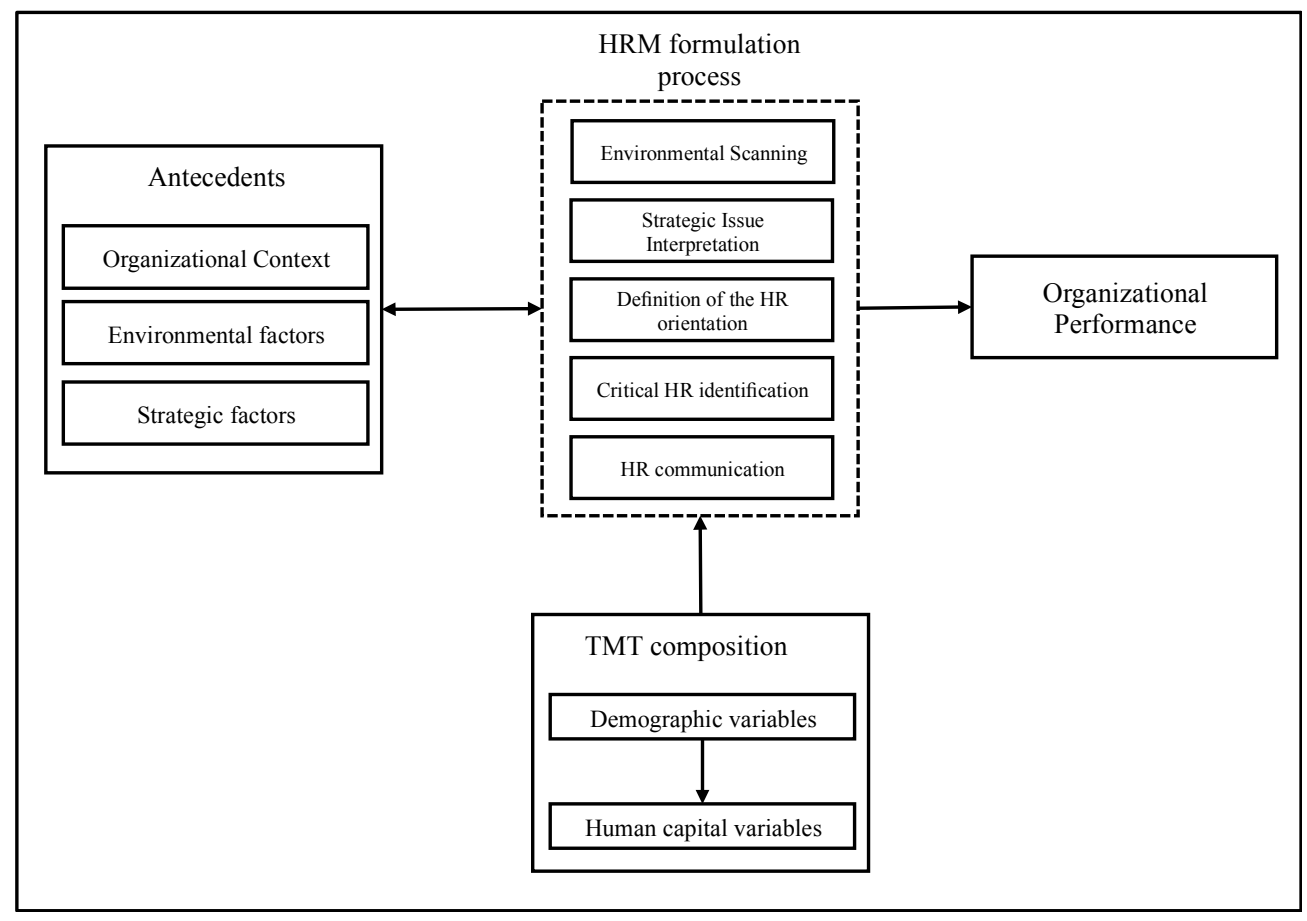

Figure 3. An integrative model for HRM strategy formulation process

Source: Own elaboration 


\section{References}

Ansoff, H.I. (1980). Strategic Issue Management. Strategic Management Journal, 1(2), 131-148. http://dx.doi.org/10.1002/smj.4250010204

Balkin, D., \& Bannister, B. (1993). Explaining pay forms for strategic employee groups in organizations: a resource dependence perspective. Journal of Occupational and Organizational Psychology, 66(2), 139-151. http://dx.doi.org/10.1111/j.2044-8325.1993.tb00523.x

Becker, B. E., \& Huselid, M. A. (2006). Strategic human resources management: where do we go from here?. Journal of Management, 32(6), 898-925. http://dx.doi.org/10.1177/0149206306293668

Boon, C., Paauwe J., Boselie, P., \& Den Hartog, D. (2009). The Netherlands institutional pressures and HRM: developing institutional fit. Personnel Review, 38(5), 492-508. http://dx.doi.org/10.1108/00483480910978018

Bowen, D.E., \& Ostroff, C. (2004). Understanding HRM-firm performance linkages: the role of the "strength" of the system of the HRM system. Academy of Management Review, 29(2), 203-221. http://dx.doi.org10.5465/AMR.2004.12736076

Brewster, C. (1993). Developing a 'European' model of human resource management. The International Journal of Human Resource Management, 4(4), 765-784. http://dx.doi.org/10.1080/09585199300000057

Brewster, C. (1995). Towards a European model of human resource management. Journal of International Business Studies, 26(1), 1-21. http://www.jstor.org/stable/155475

Brewster, C. (1999). Strategic human resource management: the value of different paradigms. Management International Review, 39(3), 45-64. http://www.jstor.org/stable/40835830

Burke, L.A., \& Miller, M.K. (1999). Taking the mystery out of intuitive decision making. Academy of Management Executive, 13(4), 91-99. http://dx.doi.org/10.5465/AME.1999.257055

Carmeli, A., \& Schaubroeck, J. (2005). How leveraging human resource capital with its competitive distinctiveness enhances the performance of commercial and public organization. Human Resource Management, 44(4), 391-412. http://dx.doi.org/10.1002/hrm.20081

Chattopadhyay, P., Glick, H.B., \& Huber, G.P. (2001). Organizational actions in response to threats and opportunities. Academy of Management Journal, 44(5), 937-955. http://dx.doi.org/10.2307/3069439

Chen, H.M., \& Chang, W.Y. (2010). The essence of the competence concept: Adopting an organization's sustained competitive advantage viewpoint. Journal of Management and Organization, 16(5), 677-699.

Cowan, D. A. (1986). Developing a process model of problem recognition. Academy of Management Review, 11(4), 763-776. http://dx.doi.org/10.5465/AMR.1986.4283930

Delery, J.E., \& Doty, D.H. (1996). Modes of theorizing in strategic human resource management: test of universalistic, contingency, and configurational performance predictions. Academy of Management Journal, 39(4), 802-835. http://dx.doi.org/10.2307/256713

Den Hertog, F., Iterson, A.V., \& Mari, C. (2010). Does HRM really matter in bringing about strategic change?. Comparative action research in ten European steel firms. European Management Journal, $28(1), 14-24$. http://dx.doi.org/10.1016/j.emj.2008.11.002

Devanna, M.A., Fombrun, CJ., \& Tichy, N.M. (1984). A framework for strategic human resource management. En C. Fombrum, N.M. Tichy \& M.A. Devanna. Strategic Human Resource Management. New York: Wiley.

Dutton, J. E. (1993). Interpretations on automatic: a different view of strategic issue diagnosis. Journal of Management Studies, 30(3), 339-357. http://dx.doi.org/10.1111/j.1467-6486.1993.tb00308.x

Dutton, J. E., \& Duncan, R. B. (1987). The creation of momentum for change through the process of strategic issue diagnosis. Strategic Management Journal, 8(3), 279-295. http://dx.doi.org/10.1002/smj.4250080306

Dutton, J. E., Fahey, L., \& Narayanan, V. K. (1983). Toward understanding strategic issue diagnosis. Strategic Management Journal, 4(4), 307-323. http://dx.doi.org/10.1002/smj.4250040403

Elbanna, S., \& Child, J. (2007). The influence of decision, environmental and characteristics on the rationality of strategic decision making. Journal of Management Studies, 44(4), 561-591. http://dx.doi.org/10.1111/j.1467-6486.2006.00670.x 
Finkelstein, S., \& Hambrick, D. (1996). Strategic leadership: top executives and their effects on organizations. St Paul, Mn: West Publishing.

Floyd, S.W., \& Lane, P. J. (2000). Strategizing throughout the organization: managing role conflict in strategic renewal. Academy of Management Review, 25(1), 154-177. http://dx.doi.org/10.5465/AMR.2000.2791608

Forbes, D.P. (2007). Reconsidering the strategic implications of decision comprehensiveness. Academy of Management Review, 32(2), 361-376. http://dx.doi.org/10.5465/AMR.2000.2791608

Forbes, D.P., \& Milliken, F.J. (1999). Cognition and corporate governance: understanding boards of directors as strategic decision-making groups. Academy of Management Review, 24(3), 489-505. http://dx.doi.org/10.5465/AMR.1999.2202133

Ford, C. M., \& Gioia, D. A. (2000). Factors influencing creativity in the domain of managerial decision making. Journal of Management, 26(4), 705-732. http://dx.doi.org/10.1177/014920630002600406

Fredickson, J. W. (1984). The comprehensiveness of strategic decision processes: extensions, observations and future directions. Academy of Management Journal, 27(3), 445-466. http://dx.doi.org/10.2307/256039

Gallén, T. (1997). The cognitive style and strategic decisions of managers. Management Decision, 37(7), 541-551. http://dx.doi.org/10.1108/00251749710170501

Gallén, T. (2006). Managers and strategic decisions: does the cognitive style matter?. The Journal of Management Development, 25(2), 118-133. http://dx.doi.org/10.1108/02621710610645117

Golden, K.A., \& Ramanujan, V. (1985). Between a dream and a nightmare: on the integration of the human resource management and strategic business planning process. Human Resource Management, 24(4), 429-452. http://dx.doi.org/10.1002/hrm.3930240405

Grant, R. M. (2003). Strategic planning in a turbulent environment: evidence from the oil majors. Strategic Management Journal, 24(6), 491-517. http://dx.doi.org/10.1002/smj.314

Guest, D.E. (2011). Human resource management and performance: still searching for some answers. Human Resource Management Journal, 21(1), 3-13. http://dx.doi.org/10.1111/j.1748-8583.2010.00164.x

Hambrick, D.C. (2007). Upper Echelons Theory: an update. Academy of Management Review, 32(2), 334-343. http://dx.doi.org/10.5465/AMR.2007.24345254

Hambrick, D.C., \& Mason, P.A. (1984). Upper Echelons: the organization as a reflection of its top managers. Academy of Management Review, 9(2), 193-206. http://dx.doi.org/10.5465/AMR.1984.4277628

Hope-Pelled, L., Eisenhardt, K.M., \& Xin, K.R. (1999). Exploring the Black Box: an analysis of work group diversity, conflict and performance. Administrative Science Quarterly, 44(1), 1-28. http://dx.doi.org/10.2307/2667029

Hough, J. R., \& White, M. A. (2003). Environmental dynamism and strategic decision-making rationality: An examination at the decision level. Strategic Management Journal, 24(5), 481-489. http://dx.doi.org/10.1002/smj.303

Hutzschenreuter, T., \& Kleindienst, I. (2006). Strategy-process research: what have we learned and what Is still to be explored. Journal of Management, 32(5), 673-720. http://dx.doi.org/10.1177/0149206306291485

Jackson, S. E., \& Dutton, J.E. (1988). Discerning threats and opportunities. Administrative Science Quarterly, 33(3), 370-387. Retrieved from http://www.jstor.org/stable/2392714

Jackson, S. E., \& Schuler, R. S. (1995). Understanding human resource management in the context of organizations and their environment. Annual Review of Psychology, 46(1), 237-264.

Jackson, S. E., Schuler, R. S., \& Rivero, J. C. (1989). Organizational characteristics as predictors of personnel practices. Personnel Psychology, 42(4), 727-786. http://dx.doi.org/10.1111/j.1744-6570.1989.tb00674.x

Jehn, K.A., Northcraft, G.B., \& Neale, M.A. (1999). Why differences make a difference: a field study in diversity, conflict and performance in workgroups. Administrative Science Quarterly, 44(4), 741-763. http://dx.doi.org/10.2307/2667054

Joshi, A., \& Roh, H. (2009). The role of context in work team diversity research: a meta-analytic review. Academy of Management Journal, 52(3), 599-627. http://dx.doi.org/10.5465/AMJ.2009.41331491 
Julian, S.D., \& Ofori-Dankwa, J.C. (2008). Toward an integrative cartography of two strategic issue diagnosis frameworks. Strategic Management Journal, 29(1), 93-114. http://dx.doi.org/10.1002/smj.647

Kang, S.C., \& Snell, S. (2009). Intellectual capital architectures and ambidextrous learning: a framework for human resource management. Journal of Management Studies, 16(1), 65-92. http://dx.doi.org10.1111/j.1467-6486.2008.00776.x

Khatri, N., \& Ng, H. A. (2000). The role of intuition in strategic decision making. Human Relations, 53(1), 57-86. http://dx.doi.org/10.1177/0018726700531004

Kidron, A., Tzafrir, S.S., Meshulam, I., \& Iverson, R.D. (2013). Internal integration within human resource management subsystems. Journal of Managerial Psychology, 28(6), 699-719. http://dx.doi.org10.1108/JMP-05-2012-0156

Krishnan, S.K., \& Singh, M. (2011). Strategic HRM: three-stage process and its influencing factors. South Asian Journal of Management, 18(1), 60-83.

Lawrence, B.S. (1997). The black box of organizational demography. Organization Science, 8(1), 1-22.

Lengnick-Hall, M.L., Lengnick-Hall, C.A., Andrade, L., \& Drake, B. (2009). SHRM: the evolution of the field. Human Resource Management Review, 19(2), 64-85. http://dx.doi.org/10.1016/j.hrmr.2009.01.002

Lepak, D., \& Snell, S. (1999). The human resource architecture: toward a theory of human capital allocation and development. Academy of Management Review, 24(1), 31-48. http://dx.doi.org/10.5465/AMR.1999.1580439

Lepak, D., \& Snell, S. (2002). Examining the human resource architecture: the relationships among human capital, employment, and human resource configurations. Journal of Management, 28(4), 517-543. http://dx.doi.org/10.1177/014920630202800403

Lin, N. (2001). Social capital: a theory of social structure and action. Cambridge: Cambridge University Press.

Lundy, O. (1994). From personnel management to strategic human resource management. The International Journal of Human Resource Management, 5(3), 687-720. http://dx.doi.org/10.1080/09585199400000054

Lyles, M.A., \& Mitroff, I.I. (1980). Organizational problem formulation, Administrative Science Quarterly, 25(1), 102-119. Retrieved from http://www.jstor.org/stable/2392229

Martín-Alcázar, M., Romero-Fernández, P.M., \& Sánchez-Gardey, G. (2005). Strategic human resource management: Integrating the universalistic, contingent, configurational and contextual perspectives. The International Journal of Human Resource Management, 16(5), 633-659. http://dx.doi.org/10.1080/09585190500082519

McMahan, G. C., Virick, M., \& Wright, P. M. (1999). Alternative theoretical perspectives for SHRM:p, problems, and prospects. In P. Wright, L. Dyer, J. Boudreau, \& G. Milkovich (Eds.), Research in personnel and Human Resource Management (pp. 99-122). Greenwich, CT: JAI Press.

Mello, J.A. (2001). Strategic Human Resource Management. Cincinnati: South Western.

Miles, R., \& Snow, C. (1984). Designing strategic human resource systems. Organizational Dynamics, verano, 36-52. http://dx.doi.org /10.1016/0090-2616(84)90030-5

Miller, C. C., \& Ireland, R. D. (2005). Intuition in strategic decision making: friend or foe in the fast-paced 21st century?. Academy of Management Executive, 19(1), 19-30. http://dx.doi.org/10.5465/AME.2005.15841948

Miller, C.C. (2008). Decisional comprehensiveness and firm performance: towards a more complete understanding. Journal of Behavioral Decision Making, 21, 598-620. http://dx.doi.org/10.1002/bdm.607

Milliken, F. J. (1990). Perceiving and interpreting environmental change: an examination of college administrators' interpretation of changing demographies. Academy of Management Journal, 33(1), 42-63. http://dx.doi.org/10.2307/256351

Milliken, F. J., \& Martins, L. (1996). Searching for common threads: understanding the multiple effects of diversity in organizational groups. Academy of Management Review, 21(2), 402-433. http://dx.doi.org/10.5465/AMR.1996.9605060217

Mintzberg, H., \& Waters, J. (1985). Of strategies, deliberate and emergent. Strategic Management Journal, 6(3), 257-272. http://dx.doi.org/10.1002/smj.4250060306

Nielsen, S. (2010). Top management team diversity: a review of theories and methodologies. The International journal of management reviews, 12(3), 1-17. http://dx.doi.org/10.1111/j.1468-2370.2009.00263.x 
Noble, C. H. (1999). The eclectic roots of strategy implementation research. Journal of Business Research, 45(2), 119-134. http://dx.doi.org/10.1016/S0148-2963(97)00231-2

Paauwe, J. (2009). HRM performance: achievements, methodological issues and prospects. Journal of Management Studies, 46(1), 129-142. http://dx.doi.org/10.1111/j.1467-6486.2008.00809.x

Peery, N.S., \& Salem, M. (1993). Strategic management of emerging human resource issues. Human Resource Development Quarterly, 4(1), 81-95. http://dx.doi.org/10.1002/hrdq.3920040108

Pfeffer, J., \& Salancik, G. R. (1978). The external control of organizations: a resource dependence perspective. New York: Harper \& Row.

Raes, A.M.L., Heijltjes, M.G., Glunk, U., \& Roe, R.A. (2011). The interface of the top management team and middle managers: a process model. Academy of Management Review, 36(1), 102-126.

Rindova, V. P. (1999). What corporate boards have to do with strategy: a cognitive perspective. Journal of Management Studies, 36(7), 953-975. http://dx.doi.org/10.1111/1467-6486.00165

Samnani, A-K., \& Singh, P. (2013). Exploring the fit perspective: an ethnographic approach. Human Resource Management, 52(1), 123-144. http://dx.doi.org/10.1002/hrm.21516

Schuler, R.S., \& Jackson, S.E. (1987). Linking competitive strategies with human resource management practices. The Academy of Management Executive, 1(3), 207-219. http://dx.doi.org/10.5465/AME.1987.4275740

Schuler, R.S., \& Walker, J.W. (1990). Human resources strategy: focusing on issues and actions. Organizacional Dynamics, 19(1), 4-20.

Snell, S.A., \& Dean, J.W. (1992). Integrated manufacturing and human resource management: a human capital perspective. Academy of Management Journal, 35(3), 467-504. http://dx.doi.org/10.2307/256484

Soderquist, K. E., Papalexandris, A., Ioannou, G., \& Prastacos, G. (2010). From task-based to competency-based: a typology and process supporting a critical HRM transition. Personnel Review, 39(3), 325-346. http://dx.doi.org/10.1108/00483481011030520

Stanton, S.Y., Bartram, T., \& Leggat, S.G. (2010). Singing the same song: translating HRM messages across management hierarchies in Australian hospital. The International Journal of Human Resource Management, 21(4), 567-581. http://dx.doi.org/10.1080/09585191003612075

Tuggle, C.S., Schnatterly, K., \& Johnson, R.A. (2010). Attention patterns in the boardroom: how board composition and process affect discussion of entrepreneurial issues. Academy of Management Journal, 53(3), 550-551. http://dx.doi.org/10.5465/AMJ.2010.51468687

Ulrich, D., Brockbank, W., \& Johnson, D. (2009). The role of strategic architect in the strategic HR organization. People and Strategy, 32(1), 24-31.

Wei, L.Q., \& Lau, C.M. (2005). Market orientation, HRM, importance and competency: determinants of strategic HRM in Chinese enterprises. The International Journal of Human Resource Management, 16(10), 1901-1918. http://dx.doi.org/10.1080/09585190500298586

Wei, L.Q., Liu, J., Zhang, Y., \& Chiu, R.K. (2008). The role of corporate culture in the process of strategic human resource management: evidence from Chinese enterprises. Human Resource Management, 47(4), 777-794. http://dx.doi.org/10.1002/hrm.20244

Wright, P.M., \& McMahan, G.C. (2011). Exploring human capital: putting human back into strategic human resource management. Human Resource Management Journal, 21(2), 93-104. http://dx.doi.org/10.1111/j.1748-8583.2010.00165.x

Wright, P.M., Snell, S., \& Jacobsen, P. (2004). Current approaches to HR strategies: inside-out versus outside-in. Human Resource Planning, 27(4), 36-47. 